\title{
$\beta$-Secretase Cleavage of the Fly Amyloid Precursor Protein Is Required for Glial Survival
}

\author{
Bonnie J. Bolkan, ${ }^{1}$ Tilman Triphan, ${ }^{2}$ and Doris Kretzschmar ${ }^{1}$ \\ ${ }^{1}$ Center for Research on Occupational and Environmental Toxicology, Oregon Health and Science University, Portland, Oregon 97239 and ${ }^{2}$ Institut für \\ Zoologie III—Neurobiologie, Universitaet Mainz, 55099 Mainz, Germany
}

$\beta$-secretase (or BACE1) is the key enzyme in the production of $\beta$-amyloid $(\mathrm{A} \beta)$, which accumulates in the senile plaques characteristic for Alzheimer's disease. Consequently, the lack of BACE1 prevents $\beta$-processing of the amyloid precursor protein and A $\beta$ production, which made it a promising target for drug development. However, the loss of BACE1 is also detrimental, leading to myelination defects and altered neuronal activity, functions that have been associated with the cleavage of Neuregulin and a voltage-gated sodium channel subunit. Here we show that the Drosophila ortholog of BACE, dBACE, is required for glial survival. Cell-specific knockdown experiments reveal that this is a non-cell autonomous function, as a knockdown of dBACE in photoreceptor neurons leads to progressive degeneration of glia in their target zone, the lamina. Interestingly, this phenotype is suppressed by the loss of the fly amyloid precursor protein (APPL), whereas a secretion-deficient form of APPL enhances the degeneration. This shows that full-length APPL in neurons promotes the death of neighboring glial cells and that $\beta$-processing of APPL is needed to prevent glial death. These results therefore not only demonstrate a novel function for an APP protein in glia, but they also show this function specifically requires regulation by $\beta$-cleavage.

\section{Introduction}

$\beta$-site amyloid precursor protein cleaving enzyme 1 (BACE1) was identified by several groups as the secretase that cleaves the amyloid precursor protein (APP) at the $\mathrm{N}$-terminal $\beta$-amyloid (A $\beta$ ) site (Hussain et al., 1999; Sinha et al., 1999; Vassar et al., 1999; Yan et al., 1999; Lin et al., 2000), the first step in generating $\mathrm{A} \beta$. Therefore, BACE1 plays an important role in amyloid plaque formation, which occurs in the brains of patients with Alzheimer's disease $(\mathrm{AD})$. BACE1 is an aspartic protease that is ubiquitously expressed, but the highest levels are found in neurons and the pancreas (Mowrer and Wolfe, 2008). In contrast, its homolog BACE2 is only weakly expressed in neurons and, at least under physiological conditions, does not appear to be involved in $\mathrm{A} \beta$ production (Bennett et al., 2000; Yan et al., 2001; Fluhrer et al., 2002). Loss of BACE1 in transgenic mice models of AD prevents $\mathrm{A} \beta$ production and APP-induced phenotypes (Luo et al., 2001; Laird et al., 2005; Ohno et al., 2007). However, APP is not the sole substrate of BACE1; since its identification, several other substrates have been described, including Neuregulin 1 and the

Received Jan. 16, 2012; revised Sept. 11, 2012; accepted Sept. 15, 2012.

Author contributions: D.K. designed research; B.J.B. and T.T. performed research; B.J.B. and D.K. analyzed data; D.K. wrote the paper.

This work was supported by grants to D.K. from the Medical Research Foundation of Oregon and the Oregon Tax Check-off Program for Alzheimer's Research. B.J.B. was supported by training grants from the NIH (5T32AG023477 and 5T32HD049309) and the Oregon Tax Check-offProgram for Alzheimer's Research. We are very grateful to Roland Strauss (Universitaet Mainz, Germany) for his support of T.T. We also thank the Oregon Health and Science University imaging facility, which is supported by the National Institutes of Health (NIH) Grant P30NS061800.

Correspondence should be addressed to Doris Kretzschmar, Center for Research on Occupational and Environmental Toxicology, Oregon Health and Science University, 3181 Southwest Sam Jackson Park Road, Portland, OR 97239. E-mail: kretzsch@ohsu.edu.

DOI:10.1523/JNEUROSCI.0228-12.2012

Copyright $\odot 2012$ the authors $\quad 0270-6474 / 12 / 3216181-12 \$ 15.00 / 0$ $\beta$-subunit of a voltage-gated sodium channel (Willem et al., 2009).

The first BACE1 knock-out mice were described as healthy and fertile with no obvious phenotype (Cai et al., 2001; Roberds et al., 2001); however, later subtle defects were described in these animals, including smaller size, increased mortality within the first week, and being timid and less exploratory (Harrison et al., 2003; Dominguez et al., 2005). Eventually, it was reported that the loss of BACE1 caused a delay in myelination and thinner myelin sheaths in the central and peripheral nervous system, an effect that was attributed to the lack of Neuregulin 1 cleavage $(\mathrm{Hu}$ et al., 2006; Willem et al., 2006). In addition, it was described that the loss of BACE1 altered neuronal activity and synaptic plasticity accompanied by a decrease in cognitive performance and seizures, probably due to the effects of BACE1 on sodium channels (Laird et al., 2005; Wang et al., 2008; Hu et al., 2010; Kim et al., 2011).

We recently demonstrated that Drosophila also expresses a protein with $\beta$-secretase activity that cleaves the fly APP protein APPL. This protein, which we called dBACE, shows 50\% sequence similarity to human BACE1 and BACE2 with significantly higher conservation in the regions containing the active site aspartates (Carmine-Simmen et al., 2009). We also showed that dBACE can cleave APPL, generating an alternative C-terminal fragment (CTF) to the predominant $\alpha$-cleaved CTF. Furthermore, overexpression of $\mathrm{ABACE}$ enhanced the histological and behavioral phenotypes caused by APPL. Together, with our results that a fly $\mathrm{A} \beta$-like fragment derived from APPL is neurotoxic, this suggests that fly dBACE and its vertebrate orthologs have similar functions. We now describe that the neuronal knockdown of dBACE results in glial cell death, a function that is mediated by the lack of APPL cleavage. 


\section{Materials and Methods}

Drosophila stocks. UAS-APPL and UAS-dBACE were previously described in Carmine-Simmen et al. (2009). GMR-GAL4, elav-GAL4, repoGAL4 (M1B), act5-GAL4, tubP-GAL4, Df (2L)Exel7038, and Df(2L)N22-14 were obtained from the Bloomington Stock Center. UAS$\mathrm{APPL}^{\mathrm{SD}}$ flies were a gift from Vivian Budnick (University of Massachusetts, Worcester), and the Appl $l^{d}$ flies were kindly provided by Kalpana White (Brandeis University, MA). Appl-Gal4 was obtained from Laura Torroja (Universidad Autonoma de Madrid, Spain) and UAS-dBACE ${ }^{\mathrm{RNAi}}$ from the Vienna Drosophila RNAi Center (Vienna, Austria). dBACE point mutations were provided by the Drosophila TILLING Project. $d B A C E-G a l 4$ was constructed from a $5.2 \mathrm{~kb}$ fragment from BAC CH322-91L18. This construct, which includes $4.5 \mathrm{~kb}$ of the sequence upstream from the predicted $A B A C E$ start site was cloned into the pPTGAL vector. Fly lines carrying this construct were created by P-element transformation using BestGene. The N-terminal sAPPL fragment and the APPL-AICD were described in Wentzell et al. (2012). Flies were raised under standard conditions at $25^{\circ} \mathrm{C}$.

Quantitative reverse transcription-PCR. RNA was extracted from Drosophila as described by the Drosophila Genomics Resource Center (Bogart and Andrews, 2006) using Trizol (Invitrogen). Residual genomic DNA was degraded with DNaseI (Fermentas), and the cDNA was synthesized following the protocol of the SuperScript III Reverse Transcriptase Kit using oligo(dT)12-18 primer (Invitrogen). The quantitative PCR reaction was performed as recommended in the SYBR Green PCR Master Mix Kit (Applied Biosystems) and analyzed on a Bio-Rad iCycler iQ. As primers, we used CAAGACCATCGCTGTAGTAGTGCT and TCTGACGCGTCTTCACAAAG for dBACE and GCGGCAGCTACAACACAATA and CATCATTACCAGGGCGAAAT for the control reaction using the swiss-cheese gene. Because it has been described that the levels of dBACE are decreased 2.9-fold in response to mating (McGraw et al., 2004), we only used virgin females for this and all the other analyses. Fold changes were calculated using the Pfaffl method (Pfaffl, 2001).

Tissue sections for light microscopy and electron microscopy. Paraffin sections for light microscopy were prepared as described in Bettencourt da Cruz et al. (2005). Briefly, whole flies were fixed in Carnoy and dehydrated in an ethanol series, followed by methyl benzoate. Sections were cut at $7 \mu \mathrm{m}$ and imaged, using the autofluorescence caused by the eye pigment. For electron microscopy, ultrathin Epon plastic sections were prepared as described in Kretzschmar et al. (1997) and analyzed with an FEI Morgagni 268 electron microscope.

Measurement of the vacuolar pathology. To analyze the neurodegenerative phenotype of different genotypes, we took images from the lamina at the level of the first optic chiasm. For a double-blind analysis, pictures were analyzed without knowing the genotype, and numbered. To account for size differences of the flies, we determined the area occupied by the vacuoles and presented it as a percentage of the area of the entire lamina (cortex and neuropil) in each brain hemisphere. Areas were calculated in Photoshop as total pixel number, and the analysis completed after revealing the genotypes. As controls, we used sibling flies from the same cross, which only carried the UAS or GAL4 construct, to minimize genetic background effects. Statistics were done using one-way ANOVA and a Dunnett's post-test in cases where several experimental groups were compared with one control group. Student-Newman-Keuls tests were used when only comparing two groups.

Immunohistochemistry. Vibratome sections of fly heads were prepared as described in Drobysheva et al. (2008). After being fixed overnight in $4 \%$ paraformaldehyde and embedded in 3\% agar, heads were cut on a Vibratome Series 1000 Sectioning System at a thickness of $50 \mu \mathrm{m}$. Sections were stained with anti-REPO (1:5) and 22C10 (1:25), obtained
B
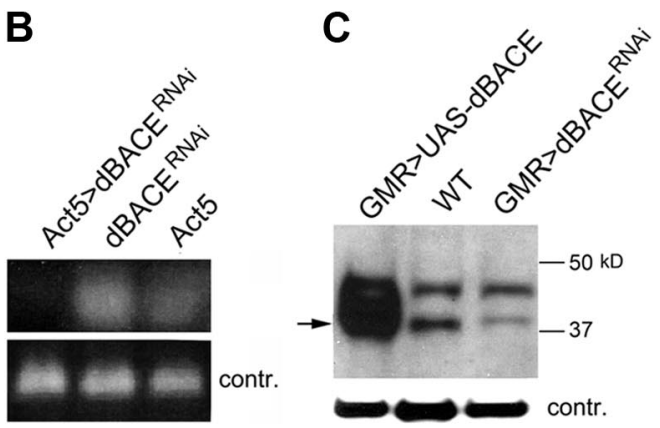

from the Developmental Studies Hybridoma Bank (DSHB). Anticleaved caspase-3 (Cell Signaling Technology) was used at 1:50, antigreen fluorescent protein (GFP; Clontech) at 1:250, and anti-APPL-CTF (a gift from Philip Copenhaver, Oregon Health and Science University) at 1:100. Anti-dBACE was raised in rabbits against a synthetic peptide containing amino acids 41-59 of the dBACE coding sequence by Davids Biotechnologie and used at a dilution of 1:500. When performing single antibody stainings, we used a biotinylated secondary antibody (1:200; Vector Laboratories) and a Cy5-conjugated streptavidin (1:100; Jackson ImmunoResearch). In the case of the double labeling with dBACE, dBACE immunoreactivity was detected using Cy2 (1:1000; Jackson ImmunoResearch), and the second protein of interest was visualized with the biotin-Cy5-strepavidin enhancement. In the case of the anti-caspase and anti-REPO double staining, the REPO immunoreactivity was enhanced with biotin-Cy5-strepavidin. All washes were performed with PBS $+0.1 \%$ Triton-X (PBST), and antibody dilutions were in PBST + $2 \%$ goat serum (Vector Laboratories). For the detection of the endogenous expression pattern of dBACE, we used $y^{1} \mathrm{w}^{1118}$ to minimize interference by the autofluorescence from the eye pigment. Images were taken on an Olympus FW1000 confocal microscope.

Western blots. Western blots were performed as described in CarmineSimmen et al. (2009). For dBACE, lysates from 10 heads were loaded on $8 \%$ SDS gels, blotted onto polyvinylidene difluoride membranes (GE Healthcare), and dBACE detected using our anti-dBACE antisera at a dilution of 1:2000. For detection of APPL and its CTFs, fresh lysates from 10 heads were loaded on a precast $10-20 \%$ Criterion Tris-HCl Gel (BioRad), and APPL detected using the anti-APPL-CTF antibody at 1:2000. For loading controls, we used anti- $\beta$-tubulin (E7; DSHB) at 1:250. Secondary horseradish peroxidase-conjugated antibodies were used at 1:10,000 (The Jackson Laboratory). dBACE and tubulin bands were visualized using the Western Lightning Chemiluminescent Reagent Plus (PerkinElmer). APPL-CTF fragments were visualized with SuperSignal West Femto Chemiluminescent Substrate (Thermo Scientific). For the analysis of endogenous full-length APPL, samples from five heads were run on 7.5\% gels and APPL detected with anti-C-term APPL. Quantification of the protein levels was done with the Odyssey infrared image system from LI-COR. LI-COR IRDye secondary antibodies were used at a dilution of 1:10,000 in LI-COR Blocking Buffer. Full-length APPL and CTF fragments were analyzed separately to optimize the conditions for their detection by Western blot analysis.

Fast phototaxis and survival. Fast phototaxis assays were conducted in the dark using the countercurrent apparatus described by Benzer (1967) and a single light source. A detailed description of the experimental conditions can be found in Strauss and Heisenberg (1993). Flies were starved overnight but had access to water and were tested the following morning. Five consecutive tests were performed in each experiment, with a time 
A

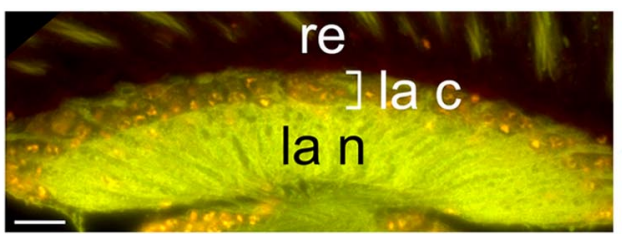

B

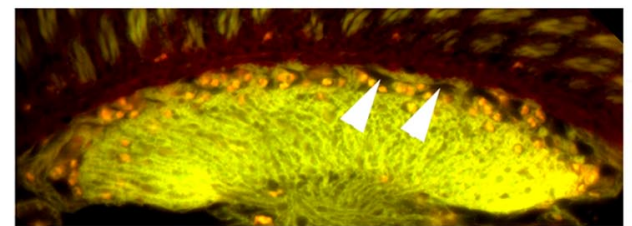

C

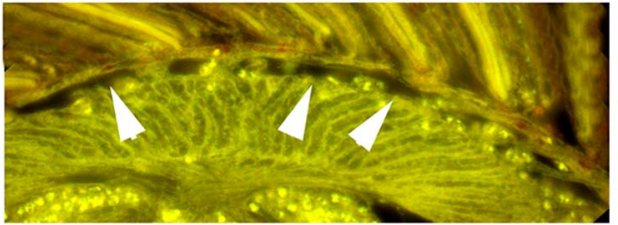

D

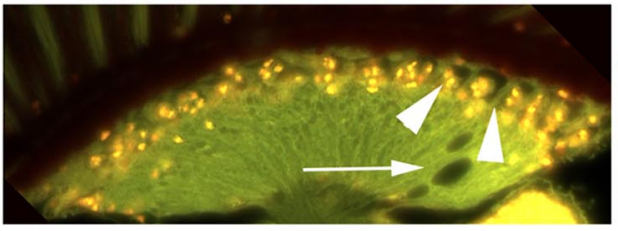

E

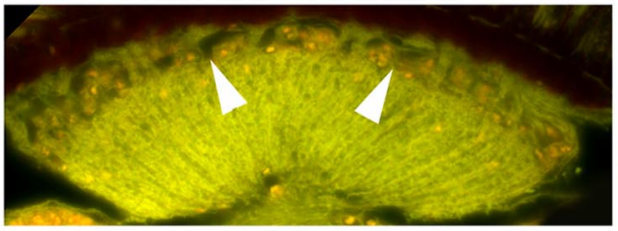

$\mathbf{F}$

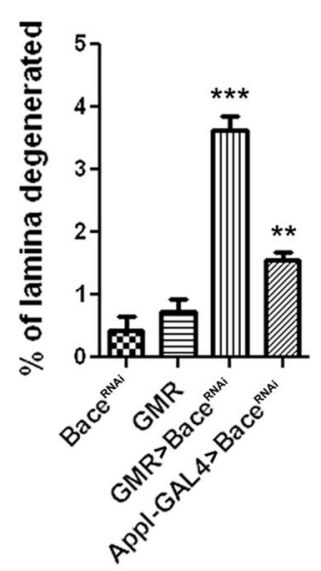

G

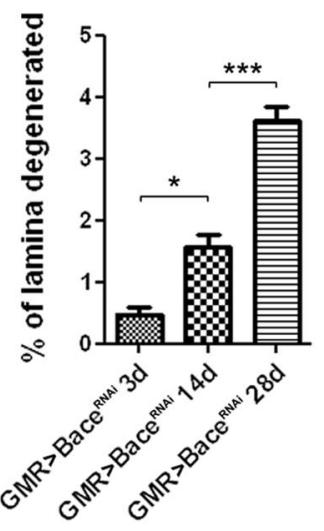

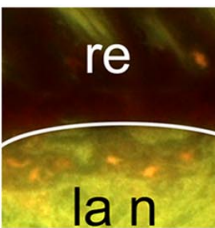

GMR
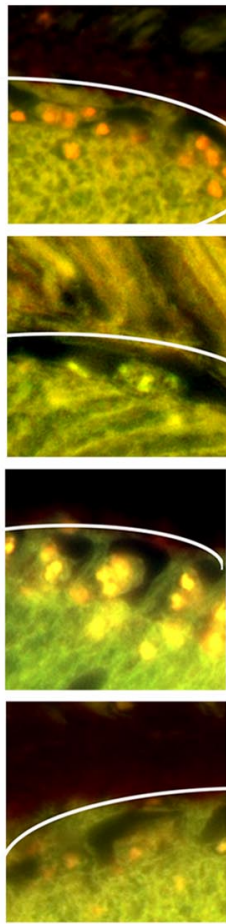

H

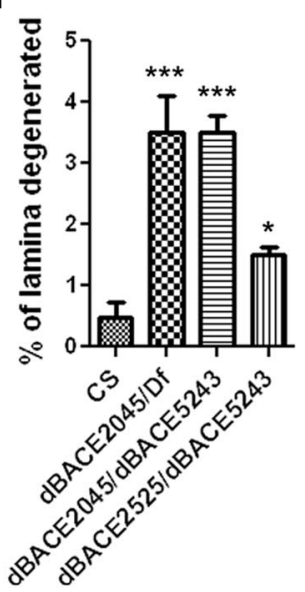

Figure 2. $\quad \mathrm{dBACE}$ mutant and knockdown flies show degeneration in the lamina. $\boldsymbol{A}, \mathrm{GMR}-\mathrm{GAL} 4$ control flies show an intact lamina neuropil (la n), which mostly consists of neuronal fibers, and lamina cortex (la c), which houses the cell bodies of the neuronal monopolar cells and various glial cells. The basement membrane, which separates the retina (re) from the lamina, is indicated by the white lines in the magnifications on the right side. $\boldsymbol{B}, \boldsymbol{C}$, Vacuoles have formed in the lamina cortex (arrowheads) after induction of the UAS-dBACE ${ }^{\text {RNAi }}$ construct via Appl-GAL ( $\boldsymbol{B}$, arrowheads) or GMR-GAL4 (C, arrowheads). A similar phenotype is detectable in flies carrying the $d B A C E^{2045}$ allele over the $\mathrm{Df}(2 \mathrm{~L})$ Exel7038 deficiency $(\boldsymbol{D})$ or over the $d B A C E^{5243}$ allele $(\boldsymbol{E})$. In addition, we can detect some vacuoles in the lamina neuropil of these flies ( $\boldsymbol{D}$, arrow). $\boldsymbol{F}$, Quantification of the degeneration in the $\mathrm{dBACE}$ knockdown flies versus controls. G, The degeneration in the retinal dBACE knockdown increases significantly with aging (3-d-old knockdown flies are not significantly different from controls). $\boldsymbol{H}$, Quantification of the degeneration in the dBACEpoint mutations compared with wild type Canton $S(C S) .{ }^{*} p<0.05,{ }^{* *} p<0.01,{ }^{* * *} p<0.001 . A-E$, All flies were $28 \mathrm{~d}$ old. Scale bar, $10 \mu \mathrm{m}$.

ferences. A Student-Newman-Keuls test was used to identify the significantly different groups. For the survival assay, a total of 1322 female flies were used for elav-GAL4; UASAPPL, and a total of 1196 for elav-GAL4; UASAPPL in the $d B A C E^{5243}$ background. Flies were kept in groups of 30-50 flies, and the vials exchanged every $4-5 \mathrm{~d}$. ANOVA and StudentNewman-Keuls tests were used for statistical analysis.

\section{Results}

Loss of dBACE results in lethality during development

To obtain mutants for dBACE, we used the Tiling Project (Winkler et al., 2005), which identified 14 lines that carried amino acid-changing point mutations in the open reading frame of $A B A C E$. For our analysis, we focused on three of these lines where the amino acid changes were predicted to have functional consequences: $d B A C E^{5243}$, which contains a substitution of $\mathrm{P}^{190}$ to $\mathrm{L} ; d B A C E^{2045}\left(\mathrm{R}^{21}\right.$ to $\mathrm{G}$ and $\mathrm{N}^{63}$ to $\mathrm{I})$; and $d B A C E^{2525}$ ( $\mathrm{S}^{207}$ to $\mathrm{L}$ ). Crossing these lines with a deficiency, Df(2L)N22-14, which deletes the chromosomal region containing $A B A C E$ (29D2), produced viable and fertile progeny in the case of $A B A C E^{2045}$ and $A B A C E^{2525}$. In contrast, no adults eclosed with $d B A C E^{5243}$, a result that was later confirmed with a smaller deficiency, Df(2L)Exel7038, after it became available. This suggests that $d B A C E^{2045}$ and $\mathrm{dBACE}^{2525}$ are hypomorphic alleles. This was supported by a Western blot analysis, which showed no or only a slight reduction in $\mathrm{dBACE}$ levels in $d B A C E^{2045}$ and no change in $d B A C E^{2525}$ (Fig. 1A, lanes 2 and 4). In contrast, heterozygous $A B A C E^{5243}$ (carried over the CyO balancer; Fig. $1 A$, lane 5) showed a clear reduction in dBACE levels (between 40 and $60 \%$, from three experiments), suggesting that the $A B A C E^{5243}$ allele expresses little or no dBACE, consistent with this allele being a null or strong hypomorph.

The requirement of $\mathrm{ABACE}$ during development was also confirmed by an RNAi-mediated knockdown of $d B A C E$. Inducing the RNAi-construct ubiquitously with the tubP-GAL4 promoter resulted in complete lethality during the late-larval/early pupal stage. Inducing the RNAi with Act5-GAL4 also resulted in the death of most animals in these stages, although a few females survived into adulthood. Quantitative reverse transcriptase PCR analysis of these females showed an almost complete loss (39-fold decrease) of the $A B A C E$ mRNA, com-

allowance of $6 \mathrm{~s}$ to make a transition toward the light and into the next vial. A minimum of 200 females, in groups of 15-25 flies, was used per age and genotype and at least 12 independent tests were performed for each condition. For aging, flies were transferred to fresh vials every $4-5 \mathrm{~d}$. ANOVA was applied to datasets of a given age to reveal significant dif- pared with control flies carrying only the RNAi construct or the Act5-GAL4 promoter construct (Fig. $1 B$ ). To verify that this lethality is due to reductions in $\mathrm{dBACE}$ levels, we performed a rescue experiment coexpressing either UAS-dBACE or UAS-GFP 
Table 1. Summary of the degeneration measurements

\begin{tabular}{|c|c|c|c|c|c|c|c|}
\hline \multicolumn{2}{|l|}{ Genotype/age } & \multicolumn{2}{|c|}{$\%$ of lamina filled by vacuoles } & SEM & Analyzed brain hemispheres & $\%$ with vacuoles & Vacuoles in lamina \\
\hline \multicolumn{2}{|l|}{ CantonS } & \multicolumn{2}{|l|}{0.485} & 0.233 & 28 & 21 & Cortex \\
\hline \multicolumn{2}{|l|}{ GMR-GAL4 $28 \mathrm{~d}$} & \multicolumn{2}{|l|}{0.716} & 0.2476 & 14 & 79 & Cortex \\
\hline \multicolumn{2}{|l|}{$\mathrm{dBACE}^{\mathrm{RNAi}} 28 \mathrm{~d}$} & \multicolumn{2}{|l|}{0.427} & 0.2288 & 7 & 43 & Cortex \\
\hline \multicolumn{2}{|l|}{ GMR-GAL4; dBACE ${ }^{\text {RNAi }} 3 \mathrm{~d}$} & \multicolumn{2}{|l|}{0.491} & 0.1118 & 32 & 50 & Cortex \\
\hline \multicolumn{2}{|l|}{ GMR-GAL4; dBACE ${ }^{\text {RNAi }} 14 \mathrm{~d}$} & \multicolumn{2}{|l|}{1.574} & 0.1996 & 12 & 100 & Cortex \\
\hline \multicolumn{2}{|l|}{ GMR-GAL4; dBACE ${ }^{\mathrm{RNAi}} 28 \mathrm{~d}$} & \multicolumn{2}{|l|}{3.614} & 0.2377 & 56 & 100 & Cortex \\
\hline \multicolumn{2}{|l|}{ GMR-GAL4; UAS-dBACE $28 \mathrm{~d}$} & \multicolumn{2}{|l|}{2.748} & 0.3852 & 18 & 100 & Cortex neuropil \\
\hline \multicolumn{2}{|l|}{ GMR-GAL4; dBACE ${ }^{\mathrm{RNAi}} ;$ UAS-dBACE $28 \mathrm{~d}$} & \multicolumn{2}{|l|}{0.555} & 0.0919 & 30 & 70 & Cortex neuropil \\
\hline \multicolumn{2}{|l|}{ Appl-GAL4; dBACE ${ }^{\text {RNAi }} 28 \mathrm{~d}$} & \multicolumn{2}{|l|}{1.547} & 0.1371 & 29 & 100 & Cortex \\
\hline \multicolumn{2}{|l|}{$\mathrm{dBACE}^{2045} / \mathrm{Df} 28 \mathrm{~d}$} & \multicolumn{2}{|l|}{3.502} & 0.5951 & 21 & 90 & Cortex neuropil \\
\hline $\mathrm{dBACE}^{2045} / \mathrm{dBACE}^{5243} 28 \mathrm{~d}$ & & 3.492 & & 0.2959 & 21 & 100 & Cortex neuropil \\
\hline $\mathrm{dBACE} \mathrm{E}^{2525} / \mathrm{dBACE}^{5243} 28 \mathrm{~d}$ & & 1.494 & & 0.1277 & 7 & 100 & Cortex neuropil \\
\hline Elav-GAL4; UAS-dBACE dBACE ${ }^{2045} / \mathrm{Df} 28 \mathrm{~d}$ & & 0.915 & & 0.3112 & 8 & 62 & Cortex neuropil \\
\hline dBACE5.4-GAL4; UAS-dBACE dBACE ${ }^{2045} / \mathrm{Df} 28$ & $28 d$ & 0.501 & & 0.1610 & 21 & 47 & Cortex neuropil \\
\hline GMR-GAL4; dBACE ${ }^{\text {RNAi; }}$ UAS-GFP $28 \mathrm{~d}$ & & 3.292 & & 0.2086 & 14 & 100 & Cortex \\
\hline GMR-GAL4;dBACE ${ }^{\text {RNAi; }}$ UAS-APPL $28 \mathrm{~d}$ & & 3.362 & & 0.2193 & 26 & 100 & Cortex neuropil \\
\hline GMR-GAL4; dBACE ${ }^{\text {RNAi } ; \text { UAS-APPL }}{ }^{\text {SD }} 28 \mathrm{~d}$ & & 8.336 & & 0.4886 & 14 & 100 & Cortex neuropil \\
\hline$A p p I^{d} ; G M R-G A L 4 ; d B A C E^{R N A i} ; 28 d$ & & 1.750 & & 0.1818 & 18 & 100 & Cortex \\
\hline GMR-GAL4; UAS-GFP $28 \mathrm{~d}$ & & 0.799 & & 0.2374 & 12 & 75 & Cortex \\
\hline GMR-GAL4; UAS-APPL $28 \mathrm{~d}$ & & 1.147 & & 0.1907 & 19 & 94 & Cortex \\
\hline GMR-GAL4; UAS-APPL ${ }^{\text {SD }} 28 \mathrm{~d}$ & & 2.348 & & 0.1585 & 15 & 100 & Cortex neuropil \\
\hline$A p p I^{d} ; G M R-G A L 4 ; 28 d$ & & 1.826 & & 0.4899 & 14 & 100 & Cortex \\
\hline Vacuoles in central brain & Area c & uoles in $\mu \mathrm{m}^{2}$ & SEM & & Analyzed brain hemispheres & $\%$ with vacuoles & $p$ value \\
\hline Appl-GAL4 28 d & 4.7 & & 0.887 & & 20 & 90 & \\
\hline Appl-GAL4; dBACE ${ }^{\text {RNAi }} 28 \mathrm{~d}$ & 34.6 & & 3.882 & & 12 & 100 & $<0.001$ \\
\hline $\mathrm{dBACE}^{2045} / \mathrm{dBACE}^{5243} 28 \mathrm{~d}$ & 18.0 & & 2.911 & & 13 & 100 & $<0.001$ \\
\hline
\end{tabular}

in $t u b P-G A L 4 / U A S-d B A C E^{\text {RNAi }}$ flies. Whereas no animals survived into adulthood with UAS-GFP (showing that the addition of a second UAS construct did not reduce the lethal effect of the UAS-RNAi construct), expression of UAS-dBACE partially rescued the lethality, with $35 \%$ of female flies eclosing.

\section{dBACE is required for the integrity of the lamina}

To determine whether dBACE mutants have an effect on the nervous system, we examined paraffin head sections from flies expressing the dBACE RNAi pan-neuronally (via Appl-GAL4). Whereas newly eclosed flies did not show a detectable phenotype (data not shown), flies aged for 4 weeks showed vacuoles in the lamina cortex (Fig. 2B, arrowheads, $F$ ) and a few scattered holes in the central brain (Table 1). A knockdown of dBACE in the retina using GMR-GAL4, which was confirmed by Western blots (Fig. 1C), induced a very similar degeneration in the lamina cortex (Fig. $2 C)$. Again, the phenotype was progressive, with significantly more vacuolization in 28 -d-old flies compared with 3 -d-old or 14-d-old (Fig. 2G; 3-d-old flies were not significantly different from controls). Interestingly, although the phenotype was more severe in the GMR-mediated knockdown (Fig. $2 F$ ), with vacuoles present along the entire lamina cortex resulting in an almost complete separation of the lamina cortex from the basement membrane (Fig. 2, white lines in magnifications), we did not detect vacuoles in the lamina neuropil or any other brain areas. This suggests a non-cell autonomous effect of the dBACE knockdown in photoreceptors on cells in the lamina cortex, indicating that the phenotype is due to the disruption of an interaction between photoreceptor axons and cells localized in the lamina cortex. The degenerative phenotype in the lamina cortex was also confirmed in 28-d-old dBACE mutants.
Both $\mathrm{dBACE}^{2525}$ and $\mathrm{dBACE}^{2045}$ showed degeneration in the lamina when in trans with the lethal $\mathrm{dBACE}^{5243}$ allele $\left(\mathrm{dBACE}^{2045} / \mathrm{dBACE}^{5243}\right.$ and $\left.\mathrm{dBACE}^{2525} / \mathrm{dBACE}^{5243}\right)$, although the phenotype was significantly less severe in $\mathrm{dBACE}^{2525}$ than $\mathrm{dBACE}^{2045}$, suggesting that $\mathrm{dBACE}^{2045}$ is a stronger hypomorph (Fig. $2 H$ ). In contrast to the retinal dBACE knockdown, $\mathrm{dBACE}^{2045} / \mathrm{dBACE}^{5243}$ and $\mathrm{dBACE}^{2045} / \mathrm{Df}(2 \mathrm{~L})$ Exel7038 deficiency flies also exhibited small vacuoles in the lamina neuropil and in the central brain (Fig. 2D, arrow; Table 1). The occurrence of vacuoles outside the lamina cortex in these genotypes (and the pan-neuronal knockdown of dBACE) suggests that the general loss of dBACE can affect the interactions of neurons with neighboring cells in many brain regions, whereas the eye-specific knockdown only interferes with the interaction between photoreceptors and cells in their target field. A summary of the statistical data are shown in Table 1.

The degeneration is rescued by dBACE expression in neurons To verify that the degenerative phenotype was due to an effect on dBACE, we coexpressed UAS-dBACE with the dBACE ${ }^{\mathrm{RNAi}}$ construct in the dBACE mutant. As controls, we analyzed sections from 4-week-old flies that express only UAS-dBACE via GMRGAL4 and found that the strong overexpression of dBACE (Fig. $1 C$, lane 1 ) also resulted in vacuole formation in the lamina (and the retina). These vacuoles, however, were distributed more randomly (Fig. 3B, arrows) and were not restricted to the lamina cortex as seen in the $\mathrm{dBACE} \mathrm{E}^{\mathrm{RNAi}}$ flies. In addition, these vacuoles were quite large, comparable to the vacuoles described in APPL or $\mathrm{dA} \beta$-overexpressing flies (Carmine-Simmen et al., 2009). Because we previously showed that $\mathrm{dBACE}$ coexpression enhances APPL-induced phenotypes (Carmine-Simmen et al., 2009), we 


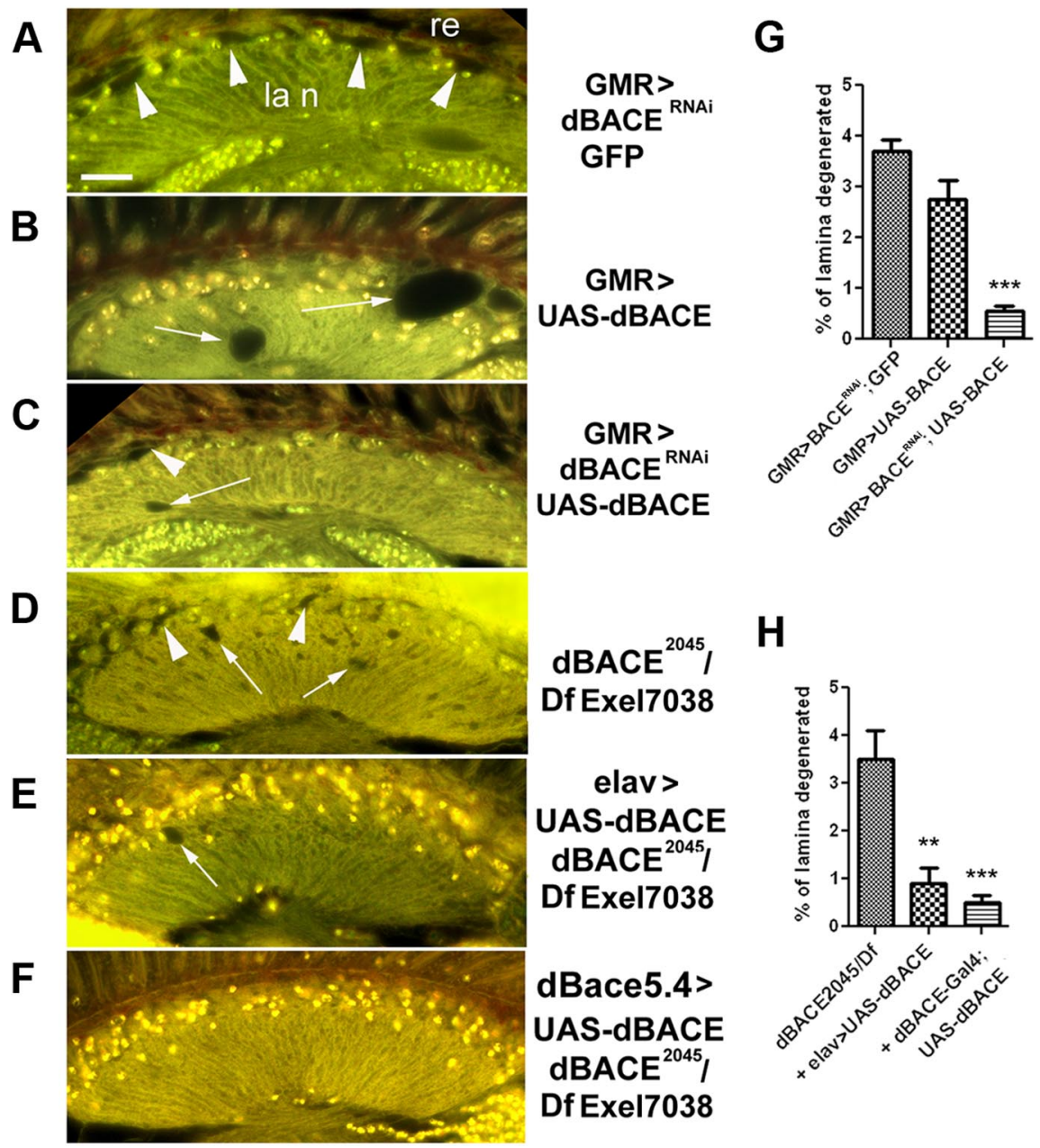

Figure 3. The degeneration is rescued by expressing dBACE. A, A GMR-GAL4; UAS-dBACE RNAi fly shows the characteristic row of vacuoles in the lamina cortex (arrowheads). $\boldsymbol{B}$, In flies overexpressing dBACE in photoreceptors we find vacuoles in the lamina neuropil (la $\mathrm{n}$ ), which can extend into the lamina cortex, but not the characteristic row of vacuoles seen in the retinal (re) knockdown flies $(\boldsymbol{A})$. $\boldsymbol{C}$, Coexpressing UAS-dBACE ${ }^{\text {RNAi }}$ with UAS-dBACE reduced the vacuoles in the lamina neuropil and cortex to the level in controls (Table 1). D, $d B A C E^{2045}$ over the Df(2L)Exel7038 showing vacuoles in the lamina cortex (arrowheads) and neuropil (arrow). $\boldsymbol{E}$, Expression of UAS-dBACE in $d B A C E^{2045} / \mathrm{Df}(2 \mathrm{~L})$ Exel7038 via elav-GAL4 reduces the degenerative phenotype although some vacuoles can still be found (arrow). $\boldsymbol{F}$, Expressing dBACE with the dBACE5.4-GAL4 promoter construct rescued the phenotype in $d B A C E^{2045} / \mathrm{Df}(2 \mathrm{~L})$ Exel7038 flies. $\mathbf{G}, \boldsymbol{H}$, Quantification of the vacuoles in rescue flies versus dBACE knockdown flies ( $\boldsymbol{G}$ ) and point mutations $(\boldsymbol{H})$. re, Retina. ${ }^{* *} p<0.01,{ }^{* * *} p<0.001$. All flies were 4 weeks old. Scale bar, $10 \mu \mathrm{m}$. pan-neuronal elav-GAL4 driver to achieve a more widespread expression of $\mathrm{dBACE}$ while minimizing overexpression phenotypes (due to the lower expression levels induced by this promoter construct). As shown in Figure 3, $E$ and $H$, we could significantly reduce the vacuolization in the lamina cortex and lamina neuropil. Finally, we used a $\mathrm{dBace-GAL4}$ promoter construct we created by inserting $5.4 \mathrm{~kb}$ of the upstream region of $d B A C E$ in front of the GAL4 promoter for rescue experiments. Using this promoter construct to express UAS-dBACE in $d B A C E^{2045}$ / Df(2L)Exel7038 transheterozygotes resulted in a complete rescue, with only occasionally a few, very small vacuoles detectable (Fig. $3 F, H)$. Together, these experiments verify that the loss of $\mathrm{dBACE}$ is indeed causing degeneration.

\section{Degeneration commences in the} subretinal layer of the lamina cortex To analyze these degenerative defects in more detail, we performed electron microscopic studies on brains from GMRGAL4; UAS-dBACE ${ }^{\text {RNAi }}$ flies. Focusing on the lamina cortex (Fig. $4 A, E$, box), we found that at $24-32 \mathrm{~h}$ posteclosion glial cells, monopolar neurons, and photoreceptor axons were present and seemingly unaffected (Fig. 4C). However, we could already detect some very small lesions close to the basement membrane (Fig. 4C, arrows). At a higher magnification (Fig. $4 G$, arrowheads), we found that these were due to a loosening of the tissue of the lamina cortex from the basement membrane (arrowheads). In addition, fingerlike extensions from the basement membrane became visible in these areas (Fig. 4G, arrow). In 14-d-old knockdown flies, the vacuoles near the basement membrane were significantly larger (Fig. assume that these large vacuoles are due to increased production of the toxic $\mathrm{dA} \beta$ fragments when $\mathrm{dBACE}$ is overexpressed. We currently do not know the cellular mechanisms that result in the different types of vacuole formation; however, the large size of the vacuoles induced by overexpression of APPL/dA $\beta / \mathrm{dBACE}$ could be due to the deleterious effects of a dying neuron on neighboring neurons and axons, possibly caused by the release of $\mathrm{dA} \beta$. Although expression of UAS-dBACE also resulted in vacuoles, we found that coexpressing it with UAS-dBACE ${ }^{\mathrm{RNAi}}$ rescued the vacuolization in the lamina (Fig. $3 G$ ), with only some small vacuoles still detectable in the lamina cortex and/or lamina neuropil (Fig. 3C, arrowhead and arrow). In contrast, coexpressing UAS-GFP (as a control to account for the number of UAS constructs) had no effect on the dBACE knockdown phenotype (Fig. $3 A$ ). To confirm the rescue experiments, we also expressed $\mathrm{dBACE}$ in the $d B A C E^{2045}$ mutant over the $\mathrm{Df}(2 \mathrm{~L})$ Exel7038 deficiency. In addition to lesions in the lamina cortex, 4-week-old $d B A C E^{2045}$ / $\operatorname{Df}(2 \mathrm{~L})$ Exel7038 flies show vacuole formation in the lamina neuropil (Fig. 3D, arrows) in $94 \%$ of the flies $(n=39)$. We therefore used the
$4 D$, black arrows), and the finger-like protrusions appeared more stunted (Fig. $4 H$, arrow). In addition, we found vacuoles in more proximal regions of the lamina cortex (Fig. 4D, white arrows), confirming the progressive nature of the degeneration. In contrast, 24-32 h (data not shown) and 14-d-old GMR-GAL4 control flies (Fig. $4 B, F$ ) did not show any of these phenotypes. That the first lesions were detectable close to the basement membrane suggested that the first cells affected are cells that are localized in this subretinal layer.

\section{dBACE is required for glial survival}

The subretinal layer of the lamina cortex contains two types of glial cells but no neuronal cell bodies, which suggested that the degeneration is due to the death of glial cells. To verify effects on glia, we performed immunohistochemical stainings on GMRGAL4;UAS-dBACE ${ }^{\text {RNAi }}$ flies, using the glial marker anti-REPO. Already in 3-d-old GMR-GAL4;UAS-dBACE ${ }^{\text {RNAi }}$ flies (Fig. 5B), we detected slight changes in the glial pattern when compared with 3-d-old (data not shown) or 3-week-old control flies carry- 

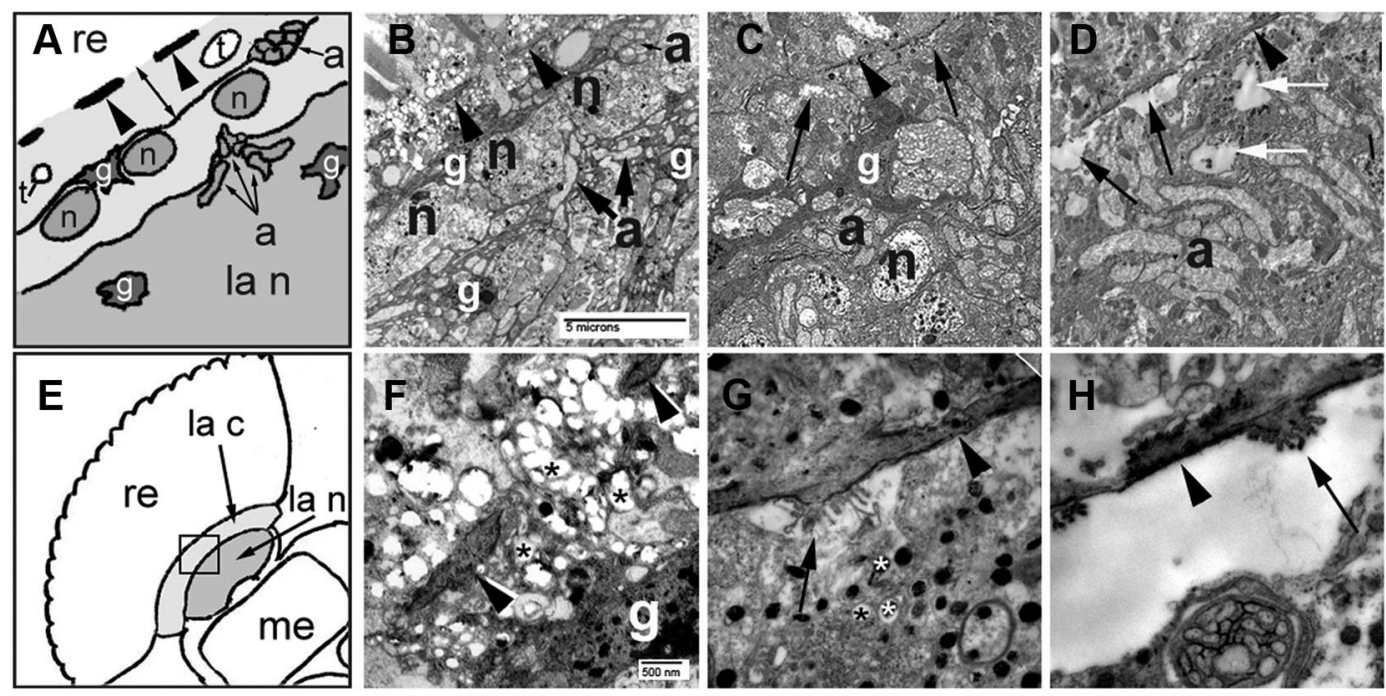

Figure 4. Electron microscopy reveals a separation of the lamina cortex from the basement membrane. $\boldsymbol{A}$, Schematic of the lamina cortex (la c) region shown in $\boldsymbol{B}$ and where it is localized in the fly head (box in E). The retina (re) is separated from the lamina cortex (light gray) by the basement membrane (arrowheads). The layer directly beneath the basement membrane (from the basement membrane to the black line) is filled with pigment vesicles and contains trachea ( $t$ ) and the fenestrated glia (not seen in this picture), but no neuronal cell bodies. The cell bodies of the neuronal monopolar cells $(\mathrm{n})$ and the satellite glia $(\mathrm{g})$ are found in the layer adjacent to the lamina neuropil (la $\mathrm{n}$; darker gray). The lamina neuropil houses the cell bodies of the epithelial glia ( $\mathrm{g}$ ) as well as axons from photoreceptors (a) and neurites from monopolar cells. $\boldsymbol{B}$, The comparable region in the lamina cortex of a 14-d-old GMR-GAL4 fly. The magnification $(\boldsymbol{F})$ shows the basement membrane (arrowheads) and pigment vesicles (asterisks). C, The lamina cortex of a 24- to 36-h-old GMR-GAL4; UAS-dBACE ${ }^{\text {RNAi }}$ fly still appears quite normal at the lower magnification (C), with glia (g), photoreceptor axons (a), and monopolar cells (n) present and only small lesions (arrows) detectable close to the basement membrane (arrowhead). $\mathbf{G}$, A higher magnification of this area reveals that these lesions seem to be due to a loosening of the lamina tissue from the basement membrane (arrowhead). In addition, finger-like extensions from the basement membrane (arrow) are detectable.

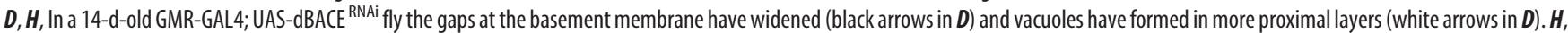
A magnification shows that the finger-like structures persist but are more stunted (arrow; the arrowhead points to the basement membrane). Scale bar in $\boldsymbol{B}$ applies to $\boldsymbol{B}-\boldsymbol{D}$; scale bar in $\boldsymbol{F}$ applies to $\boldsymbol{F}-\boldsymbol{H}$. me, medulla.

ing only GMR-GAL4 (Fig. 5A; aging did not affect the glial pattern in controls). As seen in the control flies, rows of glial cells could be detected in the subretinal layer (Fig. 5A, red arrow), which contains the fenestrated glia and the pseudocartridge glia (Kretzschmar and Pflugfelder, 2002; Edwards and Meinertzhagen, 2010). Slightly proximal to this layer, the outer satellite glia form a row on top of the neuronal monopolar cell bodies, whereas the inner satellite glia form a row proximal to the monopolar cells near the border to the lamina neuropil ( $5 \mathrm{~A}$, arrowhead). In contrast to these glial types, the epithelial glia are positioned in the distal lamina neuropil (5A, white arrow) and not in the lamina cortex. Compared with the controls, anti-REPO staining in 3-d-old GMR-GAL4; UAS-dBACE ${ }^{\text {RNAi }}$ flies was weaker and a few gaps appeared in the glial rows in the subretinal layer (Fig. 5B, red arrows). The inner satellite glia and epithelial glia also seemed less intensely stained, but there were no obvious gaps (arrowhead and white arrow). In 3-week-old knockdown flies, only a few glial cells were detectable in the subretinal layer (Fig. 5C, red arrows). Most of the remaining glia in the lamina cortex appeared to be satellite glia (arrowheads), although the general disorganization made an identification of the affected subtypes difficult (and to the best of our knowledge, no subtypespecific markers are available). Counting the REPO immunopositive cells in these flies confirmed a significant reduction compared with controls with $11.9 \pm 0.9$ positive cells in RNAi knockdown flies compared with $36.0 \pm 1.1$ immunopositive cells in control flies only expressing GMR-GAL4 ( $p<0.001$, with nine experimental and five control flies analyzed). A similar loss of glial staining was detectable in 3-week-old homozygous $d B A C E^{2045}$ flies, which also showed gaps in the rows of the glia in the subretinal layer (Fig. 5D, red arrow). Even more prominent was the loss of epithelial glia, of which only a few remained (Fig.
$5 D$, white arrow). As seen in the knockdown flies, the satellite glia (Fig. $5 D$, arrowheads) appeared to be least affected. In contrast to the glial staining, staining neurons (using anti-ELAV) did not reveal a difference between 3-week-old control and GMR; UAS$\mathrm{dBACE}^{\mathrm{RNAi}}$ flies (Fig. $5 E, F$ ). A quantitative analysis confirmed that there was no statistically significant difference in neuronal $49 \pm$ numbers between the knockdown and control flies $(45 \pm 1.8$ vs $49 \pm 2.3$ immunopositive cells, with nine experimental and seven control flies analyzed) although we did find a few less ELAV-immunopositive cells. This minor decrease could be due to a weak direct effect of the photoreceptor knockdown on the lamina monopolar cells or to a secondary effect caused by the missing glial support at this stage.

To confirm that the decrease in REPO staining is in fact due to cell death, we used a cleaved caspase-3 antibody as a marker for apoptosis. As shown in Figure 6B, we could detect single immunopositive cells in the lamina cortex of 3- to 5-d-old GMR; UAS$\mathrm{dBACE}{ }^{\mathrm{RNAi}}$ knockdown flies (arrows and arrowheads) and many of these cells were localized close to the basement membrane at the position of the fenestrated glia and pseudocartridge glia (Fig. $6 \mathrm{~B}, \mathrm{C}$, arrows). In contrast, almost no staining was detectable in controls only expressing GMR-GAL4 (Fig. 6A). Counting caspase-immunopositive cells confirmed that this difference was highly statistically significant with $0.8 \pm 0.4$ positive cells (from six animals) in the controls compared with $13.2 \pm 0.8$ in the knockdown flies ( $p<0.001$, nine animals). To determine the identity of the dying cells, we performed a double staining with anti-cleaved caspase- 3 and anti-REPO. As shown in Figure 6, $D-F$, all the caspase-positive cells were also labeled with anti-REPO (arrows), verifying that the degenerating cells are glial cells. In addition, most of the dying glial cells were found close to the basement membrane, whereas more proximally localized glial cells were not positive 

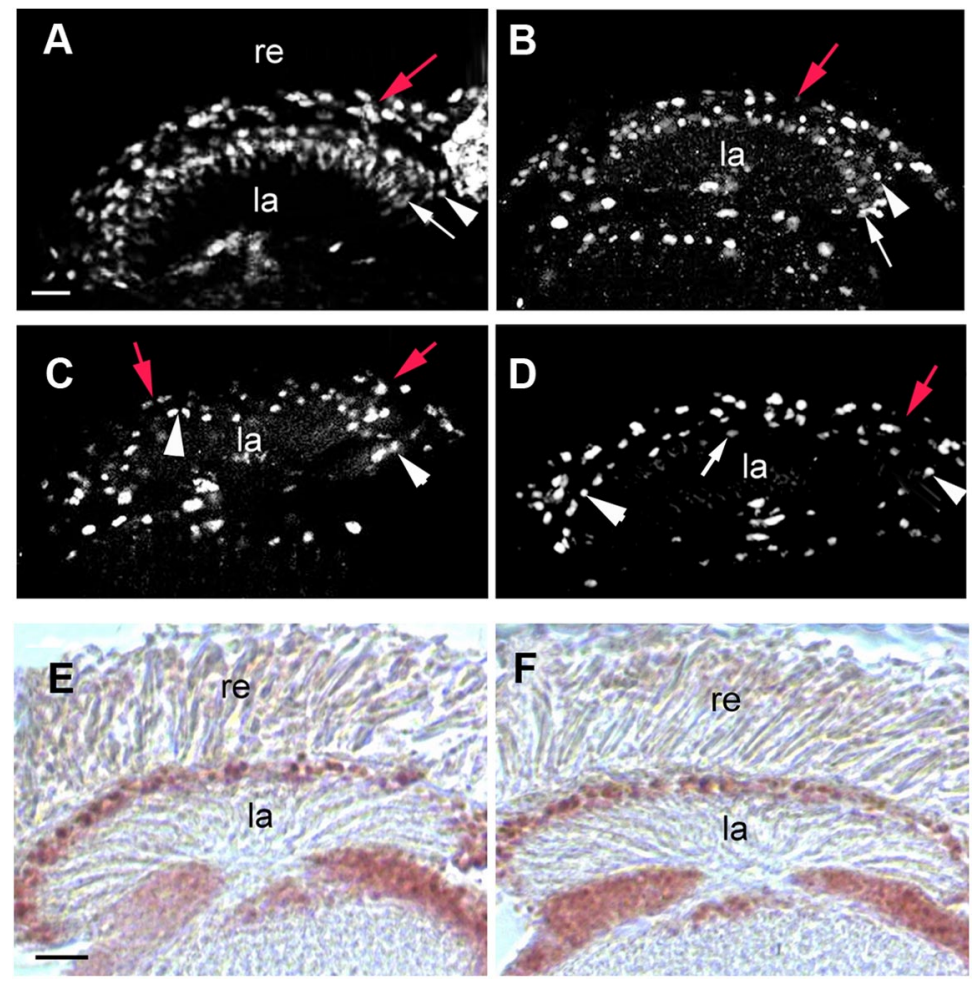

Figure 5. Loss of glial staining in the $\mathrm{dBACE}$ knockdown and mutant. $\boldsymbol{A}-\boldsymbol{D}$, Fifty micrometer vibratome head sections stained with anti-REPO. The image shows a stack of 10 confocal sections taken at $0.5 \mu \mathrm{m}$ steps. $\boldsymbol{A}$, In a 3-week-old GMR-GAL4 control fly, anti-REPO labels distal rows of glial cells (red arrow), consisting of the fenestrated glia, pseudocartridge glia, and outer satellite glia. Proximal to this region, additional glial rows are detectable, with the inner satellite glia localized in the lamina cortex (arrowhead) and the epithelial glia in the lamina neuropil (white arrow). $\boldsymbol{B}$, In a 3-d-old GMR-GAL4; UAS-dBACE ${ }^{\text {RNAi }}$ fly, gaps appear in the rows of glial cells in the subretinal layer (red arrow). The row of satellite (arrowhead) and epithelial glia (white arrow) still seems intact. C, The phenotype is more prominent after 3 weeks with only a few cells still stained in the subretinal layer (red arrows). Most of the remaining glia appears to be satellite glia (arrowheads). D, A 3-week-old dBACE 2045/Df(2L)Exel7038 fly also shows loss of glial staining, with gaps in the distal layer (red arrow) and a loss of most of the epithelial glia (white arrow), whereas the satellite glia still seemed to be present (arrowheads). $\boldsymbol{E}, \boldsymbol{F}$, Ten micrometer cryostat head sections stained with anti-ELAV show no significant difference in the staining pattern between the 3-week-old GMR-GAL4 control fly and an age-matched GMR-GAL4; UAS-dBACE ${ }^{\mathrm{RNAi}}$ fly. re, retina; la, lamina. Scale bar: (in $\left.\boldsymbol{A}, \boldsymbol{E}\right) 10 \mu \mathrm{m}$.

for anti-caspase-3 (arrowheads), supporting our observations from the electron microscopic studies that the glia in the subretinal layer are the first affected by the lack of dBACE.

\section{dBACE is expressed in neurons and axons}

As described above, glial degeneration occurs when dBACE is knocked down in photoreceptors. To determine whether dBACE is endogenously expressed in neurons, including photoreceptor, we used our anti-dBACE antibody on tissue sections. Although we showed in Western blots that this antibody does recognize dBACE, we verified its specificity on tissue sections by showing that the immunostaining was significantly reduced in a panneuronal knockdown of dBACE (using the Appl-GAL4 driver to induce dBACE RNAi) and almost completely absent in the few surviving females with the ubiquitous knockdown (via Act5CGAL4; data not shown). We found that dBACE is expressed in the brain cortex (Fig. 7A, arrow), the optic neuropils (especially the lamina and medulla, arrowheads), and the neuropils of the central brain (Fig. 7B). This widespread expression in the cortex, which houses the neuronal cell bodies, suggests that dBACE is expressed in most or all neurons. To verify neuronal expression, we performed a double-labeling experiment with the 22C10 antibody against the neuronal MAP1B ortholog Futsch (Hummel et al., 2000). Using $0.5-\mu \mathrm{m}$-thick confocal sections, we detected a significant overlap of 22C10 (red) and dBACE (green), including staining in the photoreceptor axons in the medulla (Fig. 7C, arrowheads), verifying a neuronal expression of $\mathrm{dBACE}$.

We also performed double labeling for $\mathrm{dBACE}$ and APPL to confirm that dBACE and its substrate colocalize. As previously shown, APPL (red) is expressed panneuronally (Luo et al., 1990) including the photoreceptor axons in the medulla (Fig. $7 D$, arrows). As expected, we detected APPL and dBACE in overlapping compartments in the photoreceptor axons (Fig. 7D, arrows) as well as in neuronal cell bodies within the neighboring cortex region (Fig. 7D, arrowheads). This experiment not only confirmed the neuronal expression of $\mathrm{dBACE}$ but also revealed a significant colocalization with APPL. That this includes photoreceptors is further verified by the strong coexpression of both, APPL and dBACE, within the retina (Fig. 7E). Finally, we performed an experiment to determine whether dBACE is also expressed in glia. For this experiment, we induced expression of the membranebound mCD8-GFP with repo-GAL4 to label glial membranes. As shown in Figure $7 F$, there was substantially less overlap of dBACE with this glial marker compared with the neuronal markers. Due to the close association of glial processes with neurons, we could not distinguish whether this apparent double labeling is indeed due to colocalization in some glial cells or to labeling in neurons and their adjacent ensheathing glia.

\section{Changes in APPL modify the} degenerative phenotype of the dBACE knockdown The nonautonomous effect of the GMR-GAL4-mediated knockdown of $\mathrm{dBACE}$ suggested that $\mathrm{ABACE}$ cleaves a substrate that is expressed in photoreceptors but is required for the integrity of the lamina glia. APP proteins are well known substrates of BACE, and we recently confirmed that fly dBACE does cleave fly APPL (Carmine-Simmen et al., 2009). In addition, we showed that both proteins are expressed in photoreceptors (Fig. $7 D, E$ ). It has been shown that (as with vertebrate APP) the $\mathrm{N}$ terminus of APPL can be secreted (Luo et al., 1990). We therefore investigated whether APPL, and especially its secreted fragments, are required for glial survival. To address this issue, we coexpressed constructs encoding the soluble N-terminal fragment of APPL (sAPPL; which contains the $\mathrm{N}$ terminus up to aa 758; Wentzell et al., 2012) or the intracellular domain of APPL (dAICD; Wentzell et al., 2012) with the $\mathrm{dBACE}{ }^{\mathrm{RNAi}}$ construct in the eye. To control for effects caused by the introduction of a second UAS construct, we again used UAS-GFP coexpression for comparison (Fig. 8A). However, neither of these APPL fragments had an effect on the degenerative phenotype observed in 4-week-old GMR-GAL4; UAS$\mathrm{dBACE}^{\mathrm{RNAi}}$ flies, nor did they induce a phenotype when expressed alone (data not shown). Next, we tested coexpression of full-length APPL with the RNAi knockdown and although it did not increase the degenerative phenotype in general (Fig. $8 \mathrm{E}$, left), 
we could now occasionally detect small vacuoles in the lamina neuropil (Fig. $8 B$, left, arrow). In addition, we also detected some vacuoles in the cortex of 4-week-old flies that only expressed UAS-APPL via GMR-GAL4 (Fig. 8 B, right, arrowheads). Measuring vacuole size showed that there was no increase in vacuolization in the knockdown with APPL expression when compared with the GFP control (Fig. $8 \mathrm{E}$, right). In contrast, flies lacking APPL ( $A p$ $\left.p l^{d}\right)$ exhibited a significant suppression of the dBACE knockdown phenotype with about half of the flies not showing any signs of degeneration and the other half showing only a few vacuoles (Fig. $8 C$, left, arrowhead). The suppressing effect of $A p$ $\mathrm{pl}^{d}$ was quite surprising, because we recently showed that lacking APPL can induce a degenerative phenotype in aged flies, most likely due to the loss of the protective $\alpha$-cleaved $\mathrm{N}$-terminal fragment (Wentzell et al., 2012). Although we confirmed some degeneration in the lamina cortex of $A p p l^{d}$ flies (Fig. 8C,E, right), we nevertheless detected a substantial reduction in the degeneration caused by the dBACE knockdown in the Appl d background. This suggested that the phenotype observed in dBACE mutants could be due to an increase in unprocessed full-length APPL and not to the loss of a cleavage product of APPL. To test this hypothesis, we used an APPL construct that carried a deletion in the N-terminal cleavage sites (UAS-APPL ${ }^{\mathrm{SD}}$ ), so that no secreted fragments can be produced (Torroja et al., 1999). Coexpression of this secretion-deficient construct with UAS-dBACE ${ }^{\mathrm{RNAi}}$ indeed caused a dramatic enhancement of the vacuolization in 4-weekold animals (Fig. 8C,E, left). Moreover, induction of this construct alone caused degeneration in the lamina cortex (Fig. 8D,E, right), showing that an increase in uncleaved APPL can lead to degeneration. We assume that expression of the secretiondeficient APPL construct in the dBACE knockdown further enhanced the degenerative phenotype compared to APPL SD alone because in addition to the secretion-deficient APPL, less of the endogenous APPL is processed due to the loss of dBACE. To confirm that the loss of dBACE increased the levels of uncleaved APPL, we performed Western blots using an anti-APPL antibody. Because we did not expect to see a detectable difference in the levels of endogenous APPL, which is expressed in all neurons, when $\mathrm{dBACE}$ was only knocked down in photoreceptors, we induced a pan-neuronal knockdown via Appl-GAL4 for this experiment. Although the difference was small, we detected a 1.34-fold increase in full-length APPL in the dBACE knockdown compared with controls (Fig. 9A; mean from three blots; the levels were normalized to the tubulin loading controls).

\section{Loss of dBACE reduces APPL processing and suppresses APPL-induced phenotypes}

To confirm that the knockdown of dBACE reduced the $\beta$-processing of APPL, we performed Western blots using an antisera against the $C$ terminus of APPL. Because the endogenous amount of the $\beta$-CTF is very low, we expressed additional APPL via GMR-GAL4 to increase it to detectable levels. As shown in
Figure $9 B$, lane 1 , we could detect the stronger $\alpha$-CTF $(14.5 \mathrm{kDa})$ as well as the weaker $14 \mathrm{kDa} \beta$-CTF band (arrow). Decreasing dBACE via the RNAi construct reduced the levels of the $\beta$-CTF to $\sim 40-50 \%$ (Fig. $9 B$, lane 2), similar to the reduction seen in the heterozygous $A B A C E^{5243}$ mutant (lane 3 ). In contrast, the production of the $\alpha$-CTF is increased in both cases. This result confirmed that the knockdown of $\mathrm{dBACE}$ did indeed reduce $\beta$-processing of APPL.

We also performed a behavioral analysis using the fast phototaxis assay to determine the general mobility and orientation abilities of these flies. As described previously in Carmine-Simmen et al. (2009), overexpression of APPL resulted in behavioral deficits that were enhanced by $\mathrm{dBACE}$ coexpression, presumably due to the increased production of the deleterious $\mathrm{dA} \beta$ fragment. Expressing UAS-APPL pan-neuronally with elav-GAL4 caused an age-dependent decline in their performance index (Fig. 9C), confirming our previous results. However, decreasing $\mathrm{dBACE}$ levels in these flies by crossing them to $d B A C E^{5243}$ resulted in a dramatic increase in the performance index (PI). This suppression was already detectable in 3 -d-old flies $(p<0.01)$ and became even more prominent with aging (Fig. $9 C$ ). Notably, we also observed an increase in the survival of flies heterozygous for $A B A C E^{5243}$. Whereas only $23.4 \%$ of the elav-GAL4;UAS-APPL flies were alive after $20 \mathrm{~d}$, the survival rate of elav-GAL4; UAS-APPL; $d B A C E^{5243}$ was $87.2 \%$ (Fig. 9D). These results confirmed that a reduction in $\mathrm{dBACE}$ levels, and the corresponding decrease in $\beta$-processing of APPL, has the expected beneficial effects on APPL-induced neurotoxic phenotypes.

\section{Discussion}

Originally, BACE1 knock-outs in mice were described as quite normal, providing a strong rationale that BACE inhibitors could provide a treatment for $\mathrm{AD}$. However, subsequently it has been 

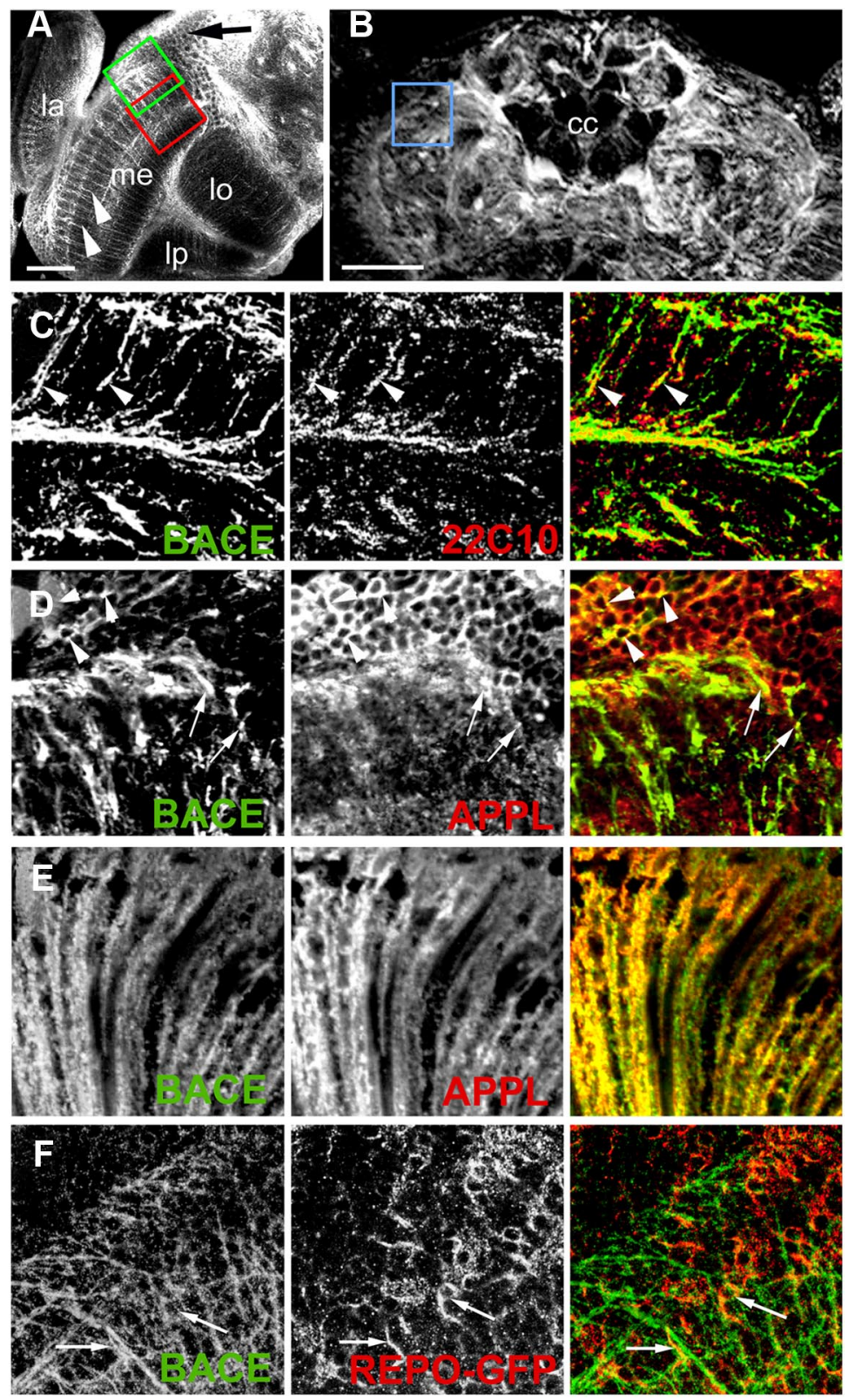

Figure 7. $\mathrm{dBACE}$ is expressed in neurons. $\boldsymbol{A}, \boldsymbol{B}$, Vibratome sections stained with anti-dBACE reveal expression in the brain cortex (arrow in $\boldsymbol{A}$; stack of $250.5 \mu \mathrm{m}$ confocal sections) and in the neuropils of the optic system ( $\boldsymbol{A}$, arrowheads) and central brain ( $\boldsymbol{B}$, shown is a stack of $110.5 \mu \mathrm{m}$ confocal sections). $C-F$, Single $0.5 \mu \mathrm{m}$ confocal sections. Shown are dBACE staining (left), staining against the indicated marker, and the overlay of both stainings (right). $\boldsymbol{C}$, A double staining with the neuronal marker $22 \mathrm{C} 10$ (red) reveals significant colocalization with $\mathrm{ABACE}$ (green), including staining in axons (arrowheads). Shown is the region indicated by the red box in $\boldsymbol{A} . \boldsymbol{D}, \boldsymbol{E}$, dBACE (green) also colocalizes with APPL (red) in the retina $(\boldsymbol{E})$ and in the brain, including staining in axons $(\boldsymbol{D}$, arrows) and cell bodies ( $\boldsymbol{D}$, arrowheads). The region shown in $\boldsymbol{D}$ is indicated by the green box in $\boldsymbol{A}$. $\boldsymbol{F}$, A glial marker (mCD8-GFP expressed by the glial repo-GAL4, in red) shows limited colocalization with dBACE (green) in a few areas (arrows). The region shown is indicated by the blue box in $\boldsymbol{B}$. la, lamina; me, medulla; Io, lobula; Ip, lobula plate; cc, central complex. Scale bar, $20 \mu \mathrm{m}$.

shown that these mice show defects in myelination and synaptic activity (Wang et al., 2008; Vassar et al., 2009; Willem et al., 2009; Kim et al., 2011), showing that BACE1 has important physiological functions. Here we have shown, that the loss of dBACE in Drosophila results in late larval/early pupal lethality, revealing that $\mathrm{dBACE}$ is an essential gene in flies. This was confirmed by the lethality of a missense mutation $\left(A B A C E^{5243}\right)$, either in homozygous flies or when in trans to deficiencies that uncover the $d B A C E$ gene. In contrast to flies, BACE1 knock-outs in mice are not lethal (Cai et al., 2001), which could be due to the existence of a second
BACE (BACE2) protein in mammals and a possible redundancy in their function. Indeed, $\mathrm{dBACE}$ is equally similar to BACE1 and BACE2 and could therefore fulfill the role of both vertebrate proteins. Alternatively, dBACE might have additional functions in flies, which are required for survival. The lethality induced by the ubiquitous knockdown of $\mathrm{dBACE}$ but not the pan-neuronal knockdown, suggests that it is due to a function of $\mathrm{dBACE}$ outside the nervous system. In fact, dBACE expression is highest in the midgut (www.flyatlas.org), and the loss of $\mathrm{dBACE}$ in this tissue could lead to the lar$\mathrm{val} /$ early pupal lethality. Because APPL is not expressed outside the nervous system, this lethality would presumably be due to the effects of dBACE on another substrate. As mentioned in the introduction, several other substrates of BACE1 have been identified in vertebrates, but so far no other targets are known in flies.

In contrast to the $d B A C E^{5243}$ allele, $d B A C E^{2045}$ and $d B A C E^{2525}$ were not lethal, and are therefore most likely hypomorphic alleles. This is in agreement with the result that these alleles showed no significant changes in the expression levels of dBACE, suggesting that both point mutations affect the function of the protein. Both of these mutants showed degeneration in the lamina when aged, although the phenotype is weaker in $d B A C E^{2525}$ flies compared with $d B A C E^{2045}$, indicating that $d B A C E^{2525}$ is a weaker hypomorph. $\mathrm{A}$ comparable phenotype was seen following both the pan-neuronal and eyespecific knockdown of dBACE, which in the latter becomes first visible (at the light microscopic level) at $14 \mathrm{~d}$ of age with small vacuoles forming in the lamina cortex that increase with further aging. This showed that $\mathrm{DBACE}$ has a nonautonomous effect; however, because the vacuoles only formed in the lamina cortex and no other areas of the brain, it suggested a short-range effect. Due to the function of $\mathrm{dBACE}$ as a protease, we assumed that this nonautonomous function is mediated via the cleavage of a substrate and the release of a soluble fragment. Indeed, we showed that the degenerative phenotype could be altered by manipulating APPL. Surprisingly, however, expression of the soluble APPL fragment did not suppress the phenotype, but removing endogenous APPL did. Although some vacuoles remained in these flies, the level of vacuolization was similar to the levels of the control $A p p l^{d}$ flies $(1.750 \%$ vs $1.826 \%$ in the controls), suggesting that removing APPL completely suppressed the dBACE-induced glial degeneration. Together, with the result that the secretion-deficient form of APPL had a strong enhancing effect and could induce degeneration in the lamina cortex by itself, this suggests that an excess of uncleaved, full-length APPL 
causes the glial death. Currently, we do not know whether this effect is due to a direct interaction of APPL with a glial protein or an indirect effect, although a direct cell-cell contact via APPL would be in agreement with the observed shortrange effect.

That only glial cells require $\mathrm{dBACE}$ activity for survival was supported by the unchanged staining pattern of the panneuronal ELAV protein and the presence of monopolar cell bodies in electron microscopy preparations from dBACE knockdown flies. However, though not significant, we did see a small reduction in the number of monopolar cells in 3-weekold dBACE knockdown flies, which we assume was a secondary effect caused by the loss of glial support. In contrast, the glial staining revealed an age-dependent decrease of REPO-positive cells in these flies, and we also found that glial cells underwent apoptotic cell death, whereas we did not observe apoptotic death of neurons. The population of apoptotic cells included glia in the subretinal layer, and as the EM studies showed, this is also the first region that is affected by the knockdown. This indicates that the fenestrated and pseudocartridge glia that are localized in this layer are the first cells to degenerate. This could be due to a higher sensitivity of these glial cells or to the closer proximity of these cells to the retina. In contrast to the effects of knocking down dBACE selectively in the retina, the point mutations and the pan-neuronal knockdown have a more widespread effect with vacuoles in the lamina neuropil and even in the central parts of the brain. As our immunohistochemical studies show, dBACE and APPL are expressed in most or all neurons, and therefore glia in other parts of the brain might also depend on $\beta$-cleavage of APPL for survival. Unfortunately, the glia in other parts of the brain is quite sparse and not arranged in a pattern that would easily allow us to detect a few missing cells; therefore our REPO stainings were inconclusive.

However, a decrease in $\mathrm{dBACE}$ can also have a positive effect, because it significantly improves the behavior and survival of APPLoverexpressing flies. We previously showed that overexpression of APPL, dBACE, or the fly $\mathrm{dA} \beta$ fragment in neurons induces behavioral deficits (Carmine-Simmen et al., 2009), all manipulations that increase $\mathrm{dA} \beta$ levels. Consequently, decreasing $\beta$-processing and therefore $\mathrm{dA} \beta$ should have a protective effect. In addition, we recently showed that increasing $\alpha$-processing has a neuroprotective effect (Wentzell et al., 2012). Therefore, the suppression of the APPL-induced phenotypes by dBACE reduction could result from a combined effect of both, the increased $\alpha$-processing and the decreased $\beta$-processing.

To the best of our knowledge a role of APP proteins in glial survival has not been described so far; however, APP, and more specifically its secreted N-terminal fragments, have been implicated in glial differentiation (Kwak et al., 2006, 2011; Vrotsos et al., 2009). N-terminal fragments of APP have been shown to have a proliferative or neurotrophic function in cell culture, whereby the $\beta$-cleaved fragment might be less effective or even deleterious (Li et al., 1997). In addition, it has been published that $\beta$-cleavage can result in an APP N-terminal fragment that binds to the DR6 death receptor after trophic factor deprivation of cultured sensory neurons, triggering neuronal death (Nikolaev et al., 2009). In contrast, our results show for the first time a role of $\beta$-cleavage in cell survival, which in addition is not mediated by the cleaved ectodomain but by the removal of the full-length protein.

\section{References}

Bennett BD, Babu-Khan S, Loeloff R, Louis JC, Curran E, Citron M, Vassar R (2000) Expression analysis of BACE2 in brain and peripheral tissues. J Biol Chem 275:20647-20651. CrossRef Medline

Benzer S (1967) Behavioral mutants of Drosophila isolated by countercurrent distripution. Proc Natl Acad Sci U S A 58:1112-1119. CrossRef Medline

Bettencourt da Cruz A, Schwärzel M, Schulze S, Niyyati M, Heisenberg M, Kretzschmar D (2005) Disruption of the MAP1B-related protein FUTSCH leads to changes in the neuronal cytoskeleton, axonal transport defects, and progressive neurodegeneration in Drosophila. Mol Biol Cell 16:2433-2442. CrossRef Medline

Bogart K, Andrews J (2006) Extraction of Total RNA from Drosophila. CGB 

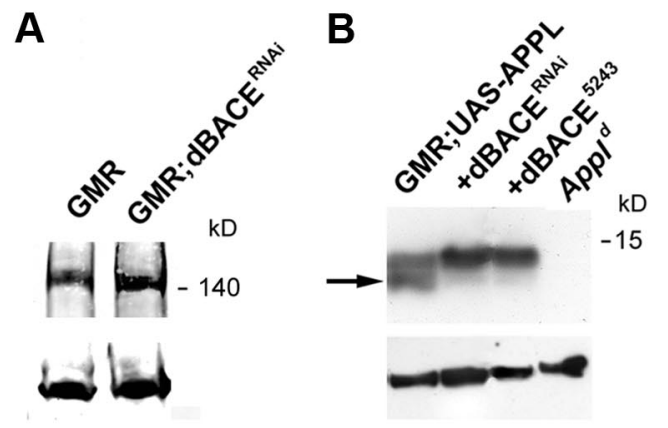

C

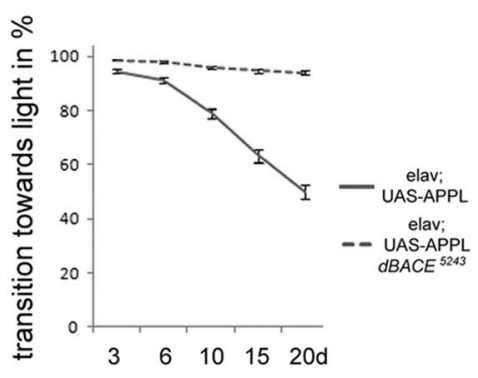

D

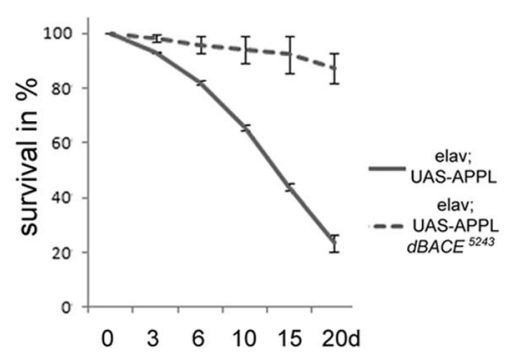

Figure 9. $\mathrm{dBACE}$ knockdown in neurons suppresses APPL-induced phenotypes. $A$, A Western blot using an anti-APPL serum against the intracellular domain reveals increased levels of the endogenous full-length APPL protein in ABACE knockdown flies compared with controls. $\boldsymbol{B}$, Using the same C-terminal antibody reveals the two alternative C-terminal cleavage products of APPL in flies expressing APPL via GMR-GAL4: the $\alpha$-cleaved CTF of $14.5 \mathrm{kDa}$ and the $14 \mathrm{kDa} \beta$-CTF (lane 1). Inducing the dBACE ${ }^{\text {RNAi }}$ construct in GMR-GAL4; UAS-APPL flies reduces the levels of the $\beta$-CTF (lane 2), as does heterozygosity for $d B A C C^{5243}$ (lane 3). As expected, flies lacking APPL (Appll) show neither cleavage product (lane 4). A loading control using anti- $\beta$-tubulin is shown below each blot. C, Fast phototaxis assays reveal a dramatic decline in the PI of flies expressing APPL pan-neuronally using elav-GAL4, whereas their performance is substantially improved by expressing APPL in flies heterozygous for the $d B A C E^{5243}$ allele. $D$, Heterozygosity for $d B A C E^{5243}$ also significantly enhances the viability of these flies. SEMs are indicated.

Technical Report 10. Bloomington, IN: The Center for Genomics and Bioinformatics.

Cai H, Wang Y, McCarthy D, Wen H, Borchelt DR, Price DL, Wong PC (2001) BACE1 is the major beta-secretase for generation of Abeta peptides by neurons. Nat Neurosci 4:233-234. CrossRef Medline

Carmine-Simmen K, Proctor T, Tschäpe J, Poeck B, Triphan T, Strauss R, Kretzschmar D (2009) Neurotoxic effects induced by the Drosophila amyloid-beta peptide suggest a conserved toxic function. Neurobiol Dis 33:274-281. CrossRef Medline

Dominguez D, Tournoy J, Hartmann D, Huth T, Cryns K, Deforce S, Serneels L, Camacho IE, Marjaux E, Craessaerts K, Roebroek AJ, Schwake M, D’Hooge R, Bach P, Kalinke U, Moechars D, Alzheimer C, Reiss K, Saftig P, De Strooper B (2005) Phenotypic and biochemical analyses of BACE1- and BACE2-deficient mice. J Biol Chem 280:30797-30806. CrossRef Medline

Drobysheva D, Ameel K, Welch B, Ellison E, Chaichana K, Hoang B, Sharma S, Neckameyer W, Srinakevitch I, Murphy KJ, Schmid A (2008) An optimized method for histological detection of dopaminergic neurons in Drosophila melanogaster. J Histochem Cytochem 56:1049-1063. CrossRef Medline

Edwards TN, Meinertzhagen IA (2010) The functional organisation of glia in the adult brain of Drosophila and other insects. Prog Neurobiol 90: 471-497. CrossRef Medline

Fluhrer R, Capell A, Westmeyer G, Willem M, Hartung B, Condron MM, Teplow DB, Haass C, Walter J (2002) A non-amyloidogenic function of BACE-2 in the secretory pathway. J Neurochem 81:1011-1020. CrossRef Medline

Harrison SM, Harper AJ, Hawkins J, Duddy G, Grau E, Pugh PL, Winter PH, Shilliam CS, Hughes ZA, Dawson LA, Gonzalez MI, Upton N, Pangalos MN, Dingwall C (2003) BACE1 (beta-secretase) transgenic and knockout mice: identification of neurochemical deficits and behavioral changes. Mol Cell Neurosci 24:646-655. CrossRef Medline

Hu X, Hicks CW, He W, Wong P, Macklin WB, Trapp BD, Yan R (2006) Bacel modulates myelination in the central and peripheral nervous system. Nat Neurosci 9:1520-1525. CrossRef Medline

Hu X, Zhou X, He W, Yang J, Xiong W, Wong P, Wilson CG, Yan R (2010) BACE1 deficiency causes altered neuronal activity and neurodegeneration. J Neurosci 30:8819-8829. CrossRef Medline

Hummel T, Krukkert K, Roos J, Davis G, Klämbt C (2000) Drosophila Futsch/22C10 is a MAP1B-like protein required for dendritic and axonal development. Neuron 26:357-370. CrossRef Medline

Hussain I, Powell D, Howlett DR, Tew DG, Meek TD, Chapman C, Gloger IS, Murphy KE, Southan CD, Ryan DM, Smith TS, Simmons DL, Walsh FS, Dingwall C, Christie G (1999) Identification of a novel aspartic protease (Asp 2) as beta-secretase. Mol Cell Neurosci 14:419-427. CrossRef Medline

Kim DY, Gersbacher MT, Inquimbert P, Kovacs DM (2011) Reduced sodium channel $\mathrm{Na}(\mathrm{v}) 1.1$ levels in BACE1-null mice. J Biol Chem 286: 8106-8116. Medline

Kretzschmar D, Pflugfelder GO (2002) Glia in development, function, and neurodegeneration of the adult insect brain. Brain Res Bull 57:121-131. CrossRef Medline

Kretzschmar D, Hasan G, Sharma S, Heisenberg M, Benzer S (1997) The swiss cheese mutant causes glial hyperwrapping and brain degeneration in Drosophila. J Neurosci 17:7425-7432. Medline

Kwak YD, Brannen CL, Qu T, Kim HM, Dong X, Soba P, Majumdar A, Kaplan A, Beyreuther K, Sugaya K (2006) Amyloid precursor protein regulates differentiation of human neural stem cells. Stem Cells Dev 15: 381-389. CrossRef Medline

Kwak YD, Marutle A, Dantuma E, Merchant S, Bushnev S, Sugaya K (2011) Involvement of notch signaling pathway in amyloid precursor protein induced glial differentiation. Eur J Pharmacol 650:18-27. CrossRef Medline

Laird FM, Cai H, Savonenko AV, Farah MH, He K, Melnikova T, Wen H, Chiang HC, Xu G, Koliatsos VE, Borchelt DR, Price DL, Lee HK, Wong PC (2005) BACE1, a major determinant of selective vulnerability of the brain to amyloid-beta amyloidogenesis, is essential for cognitive, emotional, and synaptic functions. J Neurosci 25:11693-11709. CrossRef Medline

Li HL, Roch JM, Sundsmo M, Otero D, Sisodia S, Thomas R, Saitoh T (1997) Defective neurite extension is caused by a mutation in amyloid beta/A4 (A beta) protein precursor found in familial Alzheimer's disease. J Neurobiol 32:469-480. CrossRef Medline

Lin X, Koelsch G, Wu S, Downs D, Dashti A, Tang J (2000) Human aspartic protease memapsin 2 cleaves the beta-secretase site of beta-amyloid precursor protein. Proc Natl Acad Sci U S A 97:1456-1460. CrossRef Medline

Luo LQ, Martin-Morris LE, White K (1990) Identification, secretion, and neural expression of APPL, a Drosophila protein similar to human amyloid protein precursor. J Neurosci 10:3849-3861. Medline

Luo Y, Bolon B, Kahn S, Bennett BD, Babu-Khan S, Denis P, Fan W, Kha H, Zhang J, Gong Y, Martin L, Louis JC, Yan Q, Richards WG, Citron M, Vassar R (2001) Mice deficient in BACE1, the Alzheimer's betasecretase, have normal phenotype and abolished beta-amyloid generation. Nat Neurosci 4:231-232. CrossRef Medline

McGraw LA, Gibson G, Clark AG, Wolfner MF (2004) Genes regulated by mating, sperm, or seminal proteins in mated female Drosophila melanogaster. Curr Biol 14:1509-1514. CrossRef Medline

Mowrer KR, Wolfe MS (2008) Promotion of BACE1 mRNA alternative splicing reduces amyloid beta-peptide production. J Biol Chem 283: 18694-18701. CrossRef Medline

Nikolaev A, McLaughlin T, O'Leary DD, Tessier-Lavigne M (2009) APP binds DR6 to trigger axon pruning and neuron death via distinct caspases. Nature: 457:981-989. CrossRef Medline

Ohno M, Cole SL, Yasvoina M, Zhao J, Citron M, Berry R, Disterhoft JF, Vassar R (2007) BACE1 gene deletion prevents neuron loss and memory deficits in 5XFAD APP/PS1 transgenic mice. Neurobiol Dis 26:134-145. CrossRef Medline

Pfaffl MW (2001) A new mathematical model for relative quantification in real-time RT-PCR. Nucleic Acids Res 29:e45. CrossRef Medline 
Roberds SL, Anderson J, Basi G, Bienkowski MJ, Branstetter DG, Chen KS, Freedman SB, Frigon NL, Games D, Hu K, Johnson-Wood K, Kappenman KE, Kawabe TT, Kola I, Kuehn R, Lee M, Liu W, Motter R, Nichols NF, Power M, et al. (2001) BACE knockout mice are healthy despite lacking the primary beta-secretase activity in brain: implications for Alzheimer's disease therapeutics. Hum Mol Genet 10:1317-1324. CrossRef Medline

Sinha S, Anderson JP, Barbour R, Basi GS, Caccavello R, Davis D, Doan M, Dovey HF, Frigon N, Hong J, Jacobson-Croak K, Jewett N, Keim P, Knops J, Lieberburg I, Power M, Tan H, Tatsuno G, Tung J, Schenk D, et al. (1999) Purification and cloning of amyloid precursor protein betasecretase from human brain. Nature 402:537-540. CrossRef Medline

Strauss R, Heisenberg M (1993) A higher control center of locomotor behavior in the Drosophila brain. J Neurosci 13:1852-1861. Medline

Torroja L, Packard M, Gorczyca M, White K, Budnik V (1999) The Drosophila beta-amyloid precursor protein homolog promotes synapse differentiation at the neuromuscular junction. J Neurosci 19:7793-7803. Medline

Vassar R, Bennett BD, Babu-Khan S, Kahn S, Mendiaz EA, Denis P, Teplow DB, Ross S, Amarante P, Loeloff R, Luo Y, Fisher S, Fuller J, Edenson S, Lile J, Jarosinski MA, Biere AL, Curran E, Burgess T, Louis JC, et al. (1999) Beta-secretase cleavage of Alzheimer's amyloid precursor protein by the transmembrane aspartic protease BACE. Science 286:735-741. CrossRef Medline

Vassar R, Kovacs DM, Yan R, Wong PC (2009) The beta-secretase enzyme BACE in health and Alzheimer's disease: regulation, cell biology, function, and therapeutic potential. J Neurosci 29:12787-12794. CrossRef Medline

Vrotsos EG, Kolattukudy PE, Sugaya K (2009) MCP-1 involvement in glial differentiation of neuroprogenitor cells through APP signaling. Brain Res Bull 79:97-103. CrossRef Medline

Wang H, Song L, Laird F, Wong PC, Lee HK (2008) BACE1 knock-outs display deficits in activity-dependent potentiation of synaptic transmission at mossy fiber to CA3 synapses in the hippocampus. J Neurosci 28:8677-8681. CrossRef Medline

Wentzell JS, Bolkan BJ, Carmine-Simmen K, Swanson TL, Musashe DT, Kretzschmar D (2012) Amyloid precursor proteins are protective in Drosophila models of progressive neurodegeneration. Neurobiol Dis 46: 78-87. CrossRef Medline

Willem M, Garratt AN, Novak B, Citron M, Kaufmann S, Rittger A, DeStrooper B, Saftig P, Birchmeier C, Haass C (2006) Control of peripheral nerve myelination by the beta-secretase BACE1. Science 314: 664-666. CrossRef Medline

Willem M, Lammich S, Haass C (2009) Function, regulation and therapeutic properties of beta-secretase (BACE1). Semin Cell Dev Biol 20: 175-182. CrossRef Medline

Winkler S, Schwabedissen A, Backasch D, Bökel C, Seidel C, Bönisch S, Fürthauer M, Kuhrs A, Cobreros L, Brand M, González-Gaitán M (2005) Target-selected mutant screen by TILLING in Drosophila. Genome Res 15:718-723. CrossRef Medline

Yan R, Bienkowski MJ, Shuck ME, Miao H, Tory MC, Pauley AM, Brashier JR, Stratman NC, Mathews WR, Buhl AE, Carter DB, Tomasselli AG, Parodi LA, Heinrikson RL, Gurney ME (1999) Membrane-anchored aspartyl protease with Alzheimer's disease beta-secretase activity. Nature 402:533-537. CrossRef Medline

Yan R, Munzner JB, Shuck ME, Bienkowski MJ (2001) BACE2 functions as an alternative alpha-secretase in cells. J Biol Chem 276:34019-34027. CrossRef Medline 